\title{
Zachary Swantek
}

ORCID: https://orcid.org/0000-0001-9615-2161

Seton Hall University

\section{John Paul Il's Theology of the Suffering Body}

\begin{abstract}
This article evaluates the experience of suffering and its redemptive value in the light of St. John Paul II's Theology of the Body. It begins by exploring how man was created in "the beginning," before the experience of evil and sin. Man's "original experiences" of solitude, unity and nakedness help man to understand himself as a being who is always in relation and is called to transcendence. These experiences continue to resonate within man, though sin can blind him from interpreting them correctly. Instead of man's body opening him to relations and receiving the love of God and neighbor as a gift, he often experiences shame for his disordered desires, which enclose man within himself. While shame can be a negative experience, it is also a "boundary experience," in that it points man to an original goodness that is now lacking due to the experience of evil. Suffering, likewise, can be a boundary experience that opens man, through his vulnerability, to recognizing his need for communion with God and neighbor. Christ, therefore, does not eliminate suffering but redeems it, transforming it into a revelation of God's love. Suffering has become a path to conversion, to rebuilding goodness in man's heart, and to liberation from evil. Redemption occurs when man freely opens himself to Christ's love in the midst of suffering, making up for what is "lacking" in Christ's suffering: our participation. Suffering isn't a problem to be solved so much as a mystery to enter into. Through participation in Christ's suffering, not only is man able to experience his own redemption, he can also offer his body with Christ for the redemption of the world.
\end{abstract}

\section{Keywords}

John Paul II, suffering, Theology of the Body, communion, compassion, contingency, experience, participation, redemption, transcendence. 


\section{Introduction}

St. John Paul II's Theology of the Body consists of 129 Wednesday General Audiences that he delivered between September 5, 1979 and November 28, 1984 ${ }^{1}$. He noted that the main topic that he addressed was a catechesis on "Human Love in the Divine Plan,' or with greater precision, 'The Redemption of the Body and the Sacramentality of Marriage."' 2 Therefore, it has provided a rich contribution to the Church's understanding of sexuality, marriage, family, and celibacy. However, John Paul II also noted that the catecheses were discussed on the wider basis of an "adequate anthropology" rooted in the body, which "goes far beyond the content of the reflections presented here. These reflections do not include many problems belonging, with regard to their object, to the theology of the body (e.g., the problem of suffering and death, so important in the biblical message)." 3 Thus he implies that his "reflections" are not a complete and all-encompassing theology of the body, but could continue to be developed in other areas. This paper seeks to respond to John Paul II's call to apply his theology of the body to suffering and death utilizing his "adequate anthropology," which takes into account man's embodied nature and the revelatory nature of the body. Since suffering and death are consequences of sin, and therefore intrinsically connected to the problem of evil, they must be understood in light of the redemption of the body.

The key to John Paul II's adequate anthropology is that the body is not extrinsic to salvation; it must participate and be incorporated in the process of redemption. The physical dimension is not in opposition to the spiritual dimension, but serves as a locus of experience for the unity of the person. The Catechism teaches that "As a being at once body and spirit, man expresses and perceives spiritual realities through physical signs and symbols." Man "needs signs and symbols to communicate with others. [...] The same holds true for his relationship with

1 Though John Paul II delivered 129 addresses, the English translation, Man and WomanHe Created Them: A Theology of the Body, contains 135 addresses, including 6 undelivered addresses from John Paul II's original manuscript. Cf. M. WALDSTEIN, "Introduction" in John Paul II, Man and WomanHe Created Them: A Theology of the Body. Trans. M. Waldstein. Boston 2006: Pauline Books and Media.

${ }^{2}$ John Paul II, Man and WomanHe Created Them: A Theology of the Body. Trans. M. Waldstein, Boston 2006: Pauline Books and Media, 133:1, 659.

${ }^{3}$ John Paul II, Man and Woman, 133:1, 660. 
God"4. Though God is pure spirit, His means of communicating Himself and His grace is through material elements. The body was created to be the primary sign, the "primordial sacrament" of the eternal mystery of God, through which God could reveal His love to the world. John Paul II asserts that "The body, in fact, and only the body, is capable of making visible what is invisible: the spiritual and the divine. It has been created to transfer into the visible reality of the world the mystery hidden from eternity in God, and thus to be a sign of it." 5 Thus the body has a revelatory potential, whose language man is called to listen to in order to understand himself and his relationship with his Creator. This language speaks of love, calling man to transcend himself and find fulfillment by living in communion with God and with neighbor.

However, by separating himself from God through Original Sin, man lost the ability to read the "language of the body" with the naturalness and ease that he enjoyed in the beginning. Man's bodily experience no longer speaks the language of love and communion, but that of fear and shame. In order for God to redeem man in his entirety - body and soul - God became flesh, once more opening the body as the space where God could reveal His life and love. John Paul II explains that "The fact that theology also includes the body should not astonish or surprise anyone who is conscious of the mystery and the reality of the Incarnation. Through the fact that the Word of God became flesh, the body entered theology [...] through the main door." ${ }^{36}$ Christ became flesh not to save humanity through magic words or on a purely spiritual level. He redeemed humanity precisely through his bodily suffering and death. Through his passion, Christ redeemed suffering itself, transforming an experience of evil into a place where love could be revealed and man could be redeemed. Through this, the body once again becomes transparent as the "primordial sacrament" through which the mystery of God's love can be revealed.

In this paper I will examine the redemptive value of suffering in John Paul II's Theology of the Body alongside his Apostolic Letter Salvifici doloris. I will first briefly explain John Paul II's approach (2), which appeals to an anthropology derived from both revelation and experience. Next, I will examine man's original experiences that are rooted in the body (3). These original experiences

${ }^{4}$ Catechism of the Catholic Church, 2nd ed., Vatican translation, Rome 1997: Liberia Editrice Vaticana, 1146.

5 John Paul II, Man and Woman, 19:4, 203.

${ }^{6}$ John Paul II, Man and Woman, 23:4, 221. 
help us to recognize the original goodness of Creation, which is a gift given to us by God, that calls us, in response, to make a gift of ourselves to God and neighbor. I will then show how sin and concupiscence has led to the experience of shame, and an inability to read the language of the body (4). Instead of seeing our bodies and others' as a gift, they become areas of objectification and appropriation. This is especially true of the person who is suffering, who is particularly susceptible to becoming objectified and reduced in value. Next, I will show how suffering, parallel to shame, can be a "boundary experience" through which man can recuperate the Original Experiences (5). Suffering leads man to give of himself through compassion, which allows for the rebirth of goodness in both the person who suffers and the person who shows compassion. Thus suffering can be a place where love is revealed. From there we will see how Jesus fulfills the meaning of the body and recuperates these original experiences through his suffering (6). Though the innocence of "the beginning" is lost, through Christ man is capable of redemption even during his historical existence, as he prepares for his eschatological destiny. Finally, I will show how Christ's redemption is not achieved against our will, but requires our free participation in his suffering (7).

\section{Approach: Appeal to Revelation and Experience}

It is possible to recognize a common anthropology in both John Paul II's Theology of the Body audiences (1979 -1984), and his 1984 Apostolic Letter on suffering, Salvifici doloris. In each, John Paul II's method appeals to both revelation and experience. Since man's experiences come to him through his body, John Paul II notes that "we must, for understandable reasons, appeal to experience, because bodily man is perceived by us, above all, in experience."7 The body does not signify merely the exterior dimension of man, but the meeting place and living out of man's interior life. "The body reveals man," ${ }^{8}$ and comes to signify the totality of the person's experience, that is attentive and informed by the physical body.

${ }^{7}$ John Paul II, Man and Woman, 4:4, 145.

${ }^{8}$ John Paul II, Man and Woman, 9:4, 164. Cf. 31:5, 255: "When we speak of the meaning of the body, we refer first to the full awareness of the human being." 
John Paul II divides man's experience into three historical-salvific realities, calling them a "triptych," referring to a three-paneled painting or carving, which tell a complete story in three scenes. These experiences are that of Original Man (before sin), Historical Man (fallen and redeemed) and Eschatological Man (in the final resurrection). They are not merely chronological and independent from each other, but reveal different dimensions of the mystery of man. In man's current, "historical" state, he experiences suffering and death as the effects of $\sin ^{10}$ But this is not the complete story. While we tend to normalize our fallen state, John Paul II brings our attention to the words of Jesus, who reminds us that "from the beginning it was not so" (Mt 19:8). Although it is impossible to return to this original state before the entrance of sin, evaluating man's original experience sheds light on the meaning of man's suffering and his redemption. Furthermore, since Christ identifies himself with the suffering ${ }^{11}$, and warns his disciples that they will be judged based on how they treat those who suffer ${ }^{12}$, there is an ethical value to our understanding of suffering, which will affect our eschatological fulfillment. Thus, the experience of suffering connects man with both his origin (original man) and his destiny (eschatological man), calling on him to be an active participant in Christ's redemptive suffering in his current, historical state ${ }^{13}$.

Suffering is experienced in a variety of ways, which John Paul II distinguishes as both physical and moral: "Suffering is something which is still wider than sickness, more complex and at the same time still more deeply rooted in humanity itself. A certain idea of this problem comes to us from the distinction between physical suffering and moral suffering. This distinction is based upon the double dimension of the human being and indicates the bodily and spiritual element

9 Cf. John Paul II, Man and Woman, 64:1, 380.

${ }^{10}$ Note that John Paul II makes clear that "While it is true that suffering has a meaning as punishment when it is connected with a fault, it is not true that all suffering is a consequence of a fault and has the nature of punishment." Cf. John Paul II, Apostolic Letter Salvifici doloris: "On the Christian Meaning of Human Suffering," 11. Vatican Translation. Boston: Pauline Books and Media, (1.03.1984). AAS 76 (1984), 201-50.

${ }^{11}$ Cf. Matthew 25:40: "Truly, I say to you, as you did it to one of the least of these my brethren, you did it to me".

12 Cf. Matthew 25: 34-36: "Come, O blessed of my Father, inherit the kingdom prepared for you from the foundation of the world; for I was hungry and you gave me food I was thirsty and you gave me drink, I was a stranger and you welcomed me, I was in prison and you came to me".

${ }^{13}$ Cf. Matthew 16:24: "take up your Cross and follow me." 
as the immediate or direct object of suffering. Insofar as the words 'suffering' and 'pain' can, up to a certain degree, be used as synonyms, physical suffering is present when 'the body is hurting' in some way, whereas moral suffering is 'pain of the soul.' In fact, it is a question of pain of a spiritual nature, and not only of the 'psychological' dimension of pain which accompanies both moral and physical suffering. The vastness and many forms of moral suffering are certainly no less in number than the forms of physical suffering. But at the same time, moral suffering seems, as it were, less identified and less reachable by therapy." ${ }^{14}$

Therefore the suffering person, whether suffering physically or morally, must be considered in his totality as a body-soul unity, in order to find a truly compassionate path to healing, rather than a reductive or objectifying solution. It is Christ who gives the definitive answer to man's suffering both through the love expressed in his paschal mystery, and in the call to the positive mystical experience of participation in his suffering for the redemption of the world. ${ }^{15}$

\section{The Language of the Body and the Original Experiences}

John Paul II begins his reflections by evaluating the "original experiences"of man. He notes that Jesus refers to "the beginning" in his discussion with the Pharisees, referring to man's experience before sin in the Creation accounts of Genesis 1-2. ${ }^{16}$ John Paul II notes that "by appealing 'to the beginning' [...] Christ indirectly establishes the idea of continuity and connection between the two states, thereby allowing us to go back, as it were, from the threshold of man's

${ }^{14}$ John Paul II, Apostolic Letter Salvifici doloris: "On the Christian Meaning of Human Suffering," 5. Vatican Translation. Boston: Pauline Books and Media, (1.03.1984). AAS 76 (1984), 201-50.

${ }^{15}$ Cf. Romans 8:17 and 2 Corinthians 12:7-10.

16 For John Paul II, “the beginning” signifies God's original plan for humanity, to which Jesus refers to in his dialogue with the Pharisees in Matthew 19:3-8: "And Pharisees came up to him and tested him by asking, 'Is it lawful to divorce one's wife for any cause?' He answered, 'Have you not read that he who made them from the beginning made them male and female, and said, 'For this reason man shall leave his father and mother and be joined to his wife, and the two shall become one'? So they are no longer two but one. What therefore God has joined together, let no man put asunder.' They said to him, 'Why then did Moses command one to give a certificate of divorce and put her away?' He said to them, 'For your hardness of heart Moses allows you to divorce your wives, but from the beginning it was not so." 
'historical' sinfulness to his original innocence." ${ }^{\text {17 }}$ This continuity shows that even in man's present state, he is able to find an "echo" of these original experiences in his body. Therefore, John Paul II notes that when speaking of these original experiences, "we have in mind not so much their distance in time, as rather their foundational significance. The important thing, therefore, is not that these experiences belong to man's prehistory (to his "theological prehistory"), but that they are always at the root of every human experience." ${ }^{18}$ While these experiences are written into the very language of the body, in man's fallen state he is often illiterate when it comes to reading and recognizing this language. "In the unfolding of ordinary human existence, we pay little attention to these essential experiences. Indeed, they are so interwoven with the ordinary things of life that we generally do not realize their extraordinary character." ${ }^{19}$

\subsection{Original Solitude}

The first of these original experiences is Original Solitude, based on God's words in the second Creation account, "It is not good that the man should be alone" (Gen 2:18). Man is not alone simply in that woman has not yet been created, but because man, in his bodily contact with the world, "gains consciousness of his own superiority, that is, that he cannot be put on par with any other species of living beings on the earth." ${ }^{20}$ In its negative aspect, "the body, by which man shares in the visible created world, makes him at the same time aware of being 'alone,"' ${ }^{21}$ in that "the man did not find a help similar to himself" (Gen 2:20). But in its positive aspect, man recognizes that unlike the animals, he was created "for himself,"22 that is, with the power of knowing, subjectivity and selfdetermination (free will). ${ }^{23}$

17 John Paul II, Man and Woman, 11:4, 172.

18 John Paul II, Man and Woman, 11.1, 169.

19 John Paul II, Man and Woman, 11.1, 170.

${ }^{20}$ John Paul II, Man and Woman, 5:4, 148.

${ }^{21}$ John Paul II, Man and Woman, 6:3, 152.

${ }^{22}$ Cf. Gaudium et spes, 24, in Vatican Council II, Volume 1: The Conciliar and Postconciliar Documents. Ed. A. Flannery, O.P., new rev. ed., Northport, New York 1992: Costello Publishing.

${ }^{23}$ Cf. John Paul II, Man and Woman, 5:6, 150: “Thus, consciousness reveals man as the one who possesses the power of knowing with respect to the visible world. With this knowledge, which makes him go in some way outside of his own being, man at the same time reveals himself to himself in all the distinctiveness of his being. He is not only essentially and subjectively alone. 
Through his bodily experience of the world, man is also able to recognize that he did not create himself, and therefore, his very being is a gift. "This is the body: a witness to creation as a fundamental gift, and therefore a witness to Love as the source from which this same giving springs." ${ }^{24}$ Life is not only a gift, but also leads man to recognize that he is called to a relationship with his Creator, who has given him the gift of life. ${ }^{25}$ This reveals a further aspect of solitude. "Man is 'alone': this is to say that through his own humanity, through what he is, he is at the same time set into a unique, exclusive, and unrepeatable relationship with God himself." ${ }^{26}$ Man is "a subject of the covenant," and a "partner of the Absolute"27. In this sense, man recognizes the filial meaning of his body, which points him to live in relationship of receptivity with his Creator. This filial relationship shows that man is dependent on God, because God, the original giver, is the source of life. Unlike the animals, man can understand the gift entrusted to him and recognizes that his fulfillment comes from participation in God's life, in His vision of creation. ${ }^{28}$ For "If creation is a gift given to man, [...] then its fullness and deepest dimension is determined by grace, that is, by participation in the inner life of God himself, in his holiness." ${ }^{29}$ Since God is the origin from which man proceeds, He is also the end for which he is destined. Man is always a being both from and for God.

In fact, solitude also signifies man's subjectivity, which constitutes itself through self-knowledge." 6:1, 151: "When God-Yahweh gives to the first man, formed in this way, the commandment concerning all the trees that grow in the 'garden in Eden,' above all the tree of knowledge of good and evil, this adds the aspect of choice and self-determination (that is, of free will)". 7:2, 154: "Man is a subject not only by his self-consciousness and by self-determination, but also based on his own body. The structure of this body is such that it permits him to be the author of genuinely human activity. In this activity, the body expresses the person."

${ }^{24}$ John Paul II, Man and Woman, 14:4, 183.

${ }^{25}$ Cf. John Paul II, Man and Woman, 13:4, 180: "gift indicates the one who gives and the one who receives the gift, as well as the relationship established between them."

${ }^{26}$ John Paul II, Man and Woman, 6:2, 151.

27 John Paul II, Man and Woman, 6:2, 151.

${ }^{28}$ Cf. John Paul II, Man and Woman, 13:4, 180: "creation is a gift, because man appears in it, who, as an 'image of God' is able to understand the very meaning of the gift in the call from nothing to existence. He is also able to respond to the Creator with the language of this understanding."

29 John Paul II, Man and Woman, 16:3, 191. 


\subsection{Original Unity}

Original Solitude is fulfilled in the second original experience: Original Unity. Man's body permits him to make contact with the world around him. Man cannot realize himself as the image of God in isolation, but only through the openness to which his body allows. Therefore, John Paul II notes that "When God-Yahweh says, 'It is not good that the man should be alone' (Gen 2:18), he affirms that 'alone', man does not completely realize this essence. He realizes it only by existing 'with someone' - and, put even more deeply and completely, by existing 'for someone." 30 Therefore, God created "a help" for man, whom man recognizes as "flesh from my flesh and bone from my bones" (Gen. 2:23). ${ }^{31}$ In Adam's words we recognize that it is precisely through the body of Eve that he is able to realize that she is more than a body, but somebody -- another solitude, another subject similar to himself. Furthermore, Adam is able to recognize that she also is a gift from God. In the encounter with the gift and goodness of the other, man encounters not just the person, but also the giver of the gift. Each encounter between persons becomes a definitive encounter with God as well. And since this always occurs in the body, it is not necessary to flee from the body in order to encounter God. Since each person is a being both from and for God, each human interaction between persons is, or at least should be, a loving of God in them. This has two important consequences.

First, this leads man to recognize that the other is a gift who has been entrusted to him. Since a person is a gift created by God out of love, the only appropriate response to the gift is love. ${ }^{32}$ This is done through living with and for the other, through a relationship of mutual giving. As Vatican II tells us, "man, who is the only creature on earth which God willed for itself, cannot fully find himself except through a sincere gift of self." ${ }^{33}$ Through the gift of self, the body,

30 John Paul II, Man and Woman, 14:2, 182.

31 Cf. John Paul II, Man and Woman, 10:1, 166: "the knowledge of man passes through masculinity and femininity, which are, as it were, two 'incarnations' of the same metaphysical solitude before God and the Word - two reciprocally completing ways of 'being a body' and at the same time of being human - as two complementary dimensions of self-knowledge and self-determination and, at the same time, two complementary ways of being conscious of the meaning of the body."

32 Cf. the discussion of the "Personalistic Norm" in K. Wojtyła, Love and Responsibility. San Francisco 1981: Ignatius Press, 41: "the person is a good towards which the only proper and adequate attitude is love."

${ }^{33}$ Gaudiumetspes, 24, in Vatican CouncillI, Volume 1:The ConciliarandPostconciliarDocuments. Ed. A. Flannery, O.P., new rev. ed., Costello Northport, New York 1992: Costello Publishing. 
far from isolating or separating man, allows him to transcend himself. Since man is not the image of God only in a moment, but throughout his life, the dynamism of the body shows that "man [becomes] the image of God not only through his own humanity, but also through the communion of persons, [...] Man becomes an image of God not so much in the moment of solitude as in the moment of communion [...] the image of an inscrutable divine communion of Persons." ${ }^{34}$ John Paul II calls this capacity for self-gift the "spousal meaning" of the body. ${ }^{35}$ This is particularly expressed in the communion personarum of the spouses in marriage, who make a reciprocal, exclusive and life-long gift of themselves to each other. This does not mean that it is only in marriage that man is called to give and fulfill himself; man is called to transform every moment of his life into an act of self-gift.

Secondly, since the encounter with the gift of the other is also an encounter with God, the original giver, then the communion of persons is always fruitful. A clear sign of this is procreation, which comes from the mutual gift of self of man and woman in conjugal love. In the gift of new life, the spouses recognize that in their mutual love they participate in the original fruitfulness and creativeness of God. ${ }^{36}$ This is true not only of physical paternity, but even more so of spiritual paternity. ${ }^{37}$ In spiritual fruitfulness, man fulfills his filial receptivity to God by welcoming the other as a gift, and allowing God to bear fruit through this communion.

${ }^{34}$ John Paul II, Man and Woman, 9:2, 163.

35 Cf. John Paul II, Man and Woman, 15:1, 186-187 "The human body, with its sex-its masculinity and femininity [...] contains 'from the beginning' the 'spousal' attribute, that is, the power to express love: precisely that love in which the human person becomes a gift and - through the gift-fulfills the very meaning of his being and existence."

${ }^{36}$ Cf. Genesis 4:1: "Now Adam knew Eve his wife, and she conceived and bore Cain, saying, 'I have gotten a man with the help of the LORD."' Cf. John Paul II, Man and Woman, 10:4, 169: "Procreation is rooted in creation, and every time it reproduces in some way its mystery."

${ }^{37}$ Cf. K. Wojtyła, Love and Responsibility, San Francisco 1981: Ignatius Press, 261: Wojtyła notes that spiritual paternity "as a sign of the inner maturity of the person is the goal which in diverse ways all human beings, men and women alike, are called to seek, within or outside matrimony. This call fits into the Gospel's summons to perfection of which the 'Father' is the supreme model. So then, human beings will come particularly close to God when the spiritual parenthood, of which God is the prototype, takes shape in them." 


\subsection{Original Nakedness}

The first two experiences are manifested in the third original experience of Original Nakedness, which indicates man's original state of being "naked without shame" ${ }^{38}$. This nakedness does not merely indicate a lack of clothing, but a particular purity of vision that comes from sharing in God's vision of the world. Since "God saw everything that he had made, and indeed, it was very good," (Gen 1:31) nakedness, "signifies the original good of the divine vision. It signifies the whole simplicity and fullness of this vision, which shows the 'pure' value of man as male and female, the 'pure' value of the body and of [its] sex."39 This vision grants man the possibility of living a true freedom. John Paul says that "both are 'naked,' because they are free with the very freedom of the gift." ${ }^{40}$ Since love is always given freely, original nakedness allows the person to be seen and loved purely for who they are. The body reveals the person as a gift given by the Father, to whom one has a responsibility to accept as a gift, and give oneself to and for reciprocal communion. ${ }^{41}$ Thus, "The words of Genesis 2:25, 'they did not feel shame,' do not express a lack but, on the contrary, they serve to indicate a particular fullness of consciousness and experience, above all the fullness of understanding the meaning of the body" ${ }^{\prime 2}$. In Original Nakedness, the meaning of the body and the dignity of the person, were direct, immediate, simple, full and complete.

\section{Concupiscence: Blinding to the Original Experiences}

If man was originally meant to live in relationship with God, his Creator, then $\sin$ is a denial of this, a breaking of the relationship. John Paul II explains that in order to understand the mystery of sin, one needs "to grasp the mystery of man in it who turns his back on God-Love, on the 'Father.' He, in some

${ }^{38}$ Cf. Genesis, 2:25: "And the man and his wife were both naked, and were not ashamed."

39 John Paul II, Man and Woman, 13:1, 177.

40 John Paul II, Man and Woman, 15:1, 185.

${ }^{41}$ Cf. John Paul II, Man and Woman, 17:3, 195: "We can say that inner innocence (that is, the rightness of intention) in the exchange of the gift constitutes in a reciprocal 'acceptance' of the other in such a way that it corresponds to the very essence of the gift; in this way, the mutual gift creates the communion of persons. It is a question, therefore, of 'welcoming' the other person and of 'accepting' him or her".

${ }^{42}$ John Paul II, Man and Woman, 12:2, 174. 
sense, casts him from his heart. At the same time, therefore, he detaches his heart and cuts it off, as it were, from that which 'comes from the Father': in this way, what is left in him is what 'comes from the world." 43 This is the particular effect of concupiscence, which St. John defines as: "All that is in the world, the concupiscence of the flesh, the concupiscence of the eyes, and the pride of life, comes not from the Father but from the world. And the world passes away with its concupiscence; but the one who does the will of God will remain in eternity" ( 1 Jn 2:16-17). Here there is a clear distinction between that which comes from "the Father" and that which comes from "the world," that is, concupiscence and sin. Thus there is a change in the significance of "nakedness." After sin, "what shows itself through 'nakedness' is man deprived of participation in the Gift, man alienated from Love that was the source of the original gift, the source of the fullness of good intended for the creature." ${ }^{44}$ By casting God from his heart, man is no longer capable of living the "freedom of the gift"45 in his relationship with God, with the world, others, or with himself. This leads to the experience of shame.

\subsection{A Triple Experience of Shame}

The first type of shame is a cosmic shame, which causes man to fear the world around him and the forces of nature. No longer does he see creation as a gift that points him to the goodness of the Creator. Instead, Adam's words, "I was afraid, because I am naked, and hid myself' (Gen 3:10), attest to a radical change in this relationship. Man, in some way, loses the original certainty of the image of God' expressed in his body. He also loses, in a certain way, the sense of his right to participate in the perception of the world, which he enjoyed in the mystery of creation." ${ }^{46}$ By casting God's love from his heart, man is left alone in the world, which leaves man fearful. The words of Adam also seem "to express the awareness of being defenseless, and the sense of insecurity about his somatic structure in the face of the processes of nature that operate with an inevitable

43 John Paul II, Man and Woman, 26:4, 237.

${ }^{44}$ John Paul II, Man and Woman, 27:2, 239.

45 Cf. John Paul II, Man and Woman, 32:6, 259: "Concupiscence brings with it the loss of the interior freedom of the gift." 32:6, 260: "Concupiscence, which manifests itself as a 'constraint 'sui generis' of the body', limits and restricts self-mastery from within, and thereby in some sense makes the interior freedom of the gift impossible."

${ }^{46}$ John Paul II, Man and Woman, 27:4. 
determinism." ${ }^{\prime 47}$ While man originally experienced his existence as a gift, he now experiences it along with fear, toil, suffering and ultimately death.

Man also experiences immanent shame. This is the result of a particular kind of suffering, manifested in the rupture of the body-soul unity which man enjoyed in the beginning. Rather than the body expressing the soul and the person, man now experiences conflicting desires within himself. Man experiences bodily desires contrary to the values of the person. As St. Paul describes it, "I do not understand my own actions. For I do not do what I want, but I do the very thing I hate" (Rom 7:15).

Since man's body puts him in relation with others, immanent shame is also a relative shame. This leads to looking at others not as gifts entrusted to man by God, but as objects to use for his own purposes and pleasure. "The body is left as an object of concupiscence and thus is a 'terrain of appropriation' of the other human being. [...] The relationship of the gift changes into a relationship of appropriation." ${ }^{38}$ We see the effects of this in the three-fold concupiscence.

\subsection{Threefold Concupiscence and Suffering}

In Michael Waldstein's 2006 translation of the 'Theology of the Body', he acknowledges a previous tendency in studies of Theology of the Body that reduced the concept of concupiscent desire to lust, focusing only on problems involving sexuality. ${ }^{49}$ However, John Paul II uses concupiscence in the broader sense,

${ }^{47}$ John Paul II, Man and Woman, 27:4.

${ }^{48}$ John Paul II, Man and Woman, 32:6, 260.

49 This was also the problem of translation. We can see this in the clear difference in the English translations of L'Osservatore Romano (OR) from the official Italian translation. Cf. M. Waldstein, "Introduction" in John Paul II, Man and Woman He Created Them: A Theology of the Body. Trans. M. Waldstein. Boston 2006: Pauline Books and Media, 13: "In the Italian text of [Theology of the Body] TOB, the word 'lust' (lussuria)" occurs four times. To these four one can add six additional instances of lustful (libidinoso) and eleven of 'libido' for a total of twenty- one defensible instances of 'lust.' In the OR translation, by contrast, 'lust' occurs 343 times. The main reason for this massive multiplication of 'lust' seems to lie in the RSV translation of Matthew 5:28 ('looks lustfully") When John Paul II discusses Jesus' words in detail and repeatedly uses the word 'desire' ('desidare' or desiderio') in agreement with the [Conferenz aEpiscopale Italiana] CEI translation ('looks to desire') the OR translation attempts to preserve the connection with the term 'lustfully' in the RSV and often translates 'desire' as 'lust.' It multiplies 'lust' further by frequently using it to translate 'concupiscenza.' Yet, concupiscence is a wider concept than lust. Sexual concupiscence is only one of its species. The multiplication of 'lust' introduces a note of pan-sexualism that is foreign to John Paul II." 
which can lead to the objectification of a person for a wider variety of reasons. All three types of concupiscence (concupiscence of the eyes, concupiscence of the flesh and pride of life) are interrelated and relevant when it comes to the experience of suffering.

Concupiscence of the eyes reduces the intrinsic value of the person to his utilitarian value. This can be dangerous and detrimental for a suffering person. Whether suffering physically or morally, a person may feel a sense of shame because he fears his life will be judged to have lesser value if his suffering causes him to be unproductive or a burden on others. The example Christ gives of a man looking lustfully at a woman (Mt 5:28) parallels those who look down on the suffering. In both cases, a person is perceived not for his objective value, but based upon the value placed upon him by another person. Rather than be treated as a person to be loved, the suffering person can be reduced to a problem to deal with, or worse, as an obstacle to eliminate.

Concupiscence of the flesh, the inordinate love of sensual pleasure, is related to quality of life issues. Often a person who suffers a physical or mental handicap can be viewed as lacking in dignity because he is not able to experience the same quality of life that other "normal," non-suffering people experience. A false sense of compassion is offered which seeks to free these people from suffering (or the potential for suffering) by ending their lives, which are judged as not worth living. We see this in prenatal diagnosis of genetic diseases and elective abortion, as well as euthanasia and physician-assisted suicide.

Concupiscence as "pride of life" is interrelated to this. On a direct level, pride of life is manifested as a disproportionate attachment to material goods, status, comfort and respect. Therefore, for a non-suffering person, suffering can be viewed as a threat that produces fear of losing these goods. Since suffering and death are unavoidable, often people attempt to distract themselves with worldly pleasures in order to avoid facing these existential and inevitable realities. When confronted with the suffering of another, they are reminded of their own vulnerability and potential to suffering. Their fear of the suffering is therefore really a fear for themselves and for the lifestyle in which they take pride. This is a particular threat to the man who prides himself in his self-autonomy.

On an indirect level, however, there is a fear of the suffering persons themselves. The suffering person can be viewed as an obstacle to the pursuit and realization of personal goals or other forms of fulfillment connected with their accustomed way of life. Again, this may lead the "non-suffering" to seek power over life through the promotion of laws and rights that protect their way of life, 
while denying the rights of the suffering, weak, defenseless and powerless. We see this in laws that grant the right for women to have an abortion, which in turn, denies the right to life of their child.

Another example of pride of life comes in the attempt to rationalize suffering. This is an attempt to gain control and power in the face of vulnerability. Good-natured people may try to console the suffering by trying to come up with reasons for their suffering, including how this will make them a better or stronger person. However, suffering should not be rationalized or explained away. This might lead to a temporary relief, but it denies the person the opportunity to experience the truly positive and redemptive aspects of suffering.

Through each of these experiences, we can recognize that the main value of modernity is the elimination of suffering at all costs, which does not perceive the potential opportunities for good that can come through suffering. While medical advancements have helped reduce man's suffering quantitatively, his qualitative experience of suffering has increased. ${ }^{50}$ In the attempts to numb or avoid suffering at all costs, people are denied the opportunity to make sense of their suffering, and to experience the opportunity for repentance and conversion that suffering can prompt within them. While suffering can threaten one's faith in God and the goodness of creation, it can also be an experience that confirms God's love and goodness.

\section{Suffering and the Recovery of the Original Experiences}

\subsection{Shame as a Boundary Experience}

While on the one hand shame causes man to hide himself for fear of being looked upon as an object, it also reveals to him his intrinsic dignity. While shame "reveals the moment of concupiscence, at the same time it can provide weapons ahead of time against the consequences of the threefold component of concupiscence." ${ }^{11}$ John Paul II goes so far as to say that "One can even say that, through shame, man and woman almost remain the state of original innocence."52

${ }^{50}$ Cf. S. Hauerwas, Truthfulness and Tragedy: Further Investigations into Christian Ethics. Notre Dame, IN 1977: University of Notre Dame Press, 201.

51 John Paul II, Man and Woman, 31:1, 253.

52 John Paul II, Man and Woman, 31:1, 253. 
Thus John Paul II calls shame a "boundary experience," because it points man back to the goodness of the beginning, almost to the point of restoring him to his original innocence. Since man carries the consequences of sin in his body, which is his means of openness to God and his relationships with others, it is impossible to fully return to "the Beginning" on his own. Instead, man must continue to struggle with the effects of sin, while striving to grow in virtue and self-mastery.

\subsection{Suffering as a Boundary Experience}

Suffering, like shame, is an experience that causes man to step back and question his life. In Salvifici doloris, John Paul II examines suffering and its relation to the question of evil. He notes that "Man suffers on account of evil, which is a certain lack, limitation or distortion of good. [...] Thus, in the Christian view, the reality of suffering is explained through evil, which always, in some ways, refers to a good."53 Suffering points man to a state of goodness that existed before, and that should exist, but has been twisted by evil. Thus, suffering can lead man to look back, not only to a time when he did not personally suffer, but also in search of a time when suffering itself did not exist. John Paul II notes that "by appealing 'to the beginning"' in the Gospel discussion with the Pharisees, "Christ indirectly establishes the idea of continuity and connection between the two states, thereby allowing us to go back, as it were, from the threshold of man's 'historical' sinfulness to his original innocence." ${ }^{54}$ Therefore, suffering too may be called a "boundary experience." Like shame, suffering can conceal, as well as reveal, man's original state, and the path toward its recovery. ${ }^{55}$

\subsection{Suffering and Original Solitude}

Original Solitude is the experience man has both of his dignity and of his capacity for relationship with God and others. Suffering can lead man to question

53 John Paul II, Salvifici doloris, 7.

54 John Paul II, Man and Woman, 11:4, 172.

${ }^{55}$ Cf. J. Granados, Toward a Theology of the Suffering Body, "Communio" 33, no. 4, (Winter 2006), 551: "the description of the experience of suffering offered by John Paul II in the apostolic letter Salvifici doloris runs parallel to the analysis of shame in The Theology of the Body. We could say, then, that suffering is also a boundary experience, which simultaneously veils and reveals the path toward the original state of man." 
his dignity and his value in the face of pain, due to the lack of meaning he experiences and feelings of uselessness. If there is the danger of death, man can also fear for the loss of his life. All of this leads man to ask a question: "Why?" Whether confronting one's own suffering or the suffering of others, this experience can lead to questioning the meaning of suffering and evil. This can either lead to anger, denial and rejection of God, or it can lead to a renewed relationship with God.

Though man can ask others why he has to suffer, he ultimately puts the question to God. "For man does not put the question to the world, even though it is from the world that suffering often comes to him, but he puts it to God as the Creator and Lord of the world." ${ }^{56}$ Suffering therefore, reveals to man the possibility of dialogue with God. This reveals man's unique dignity. Of all the animals, "only the suffering human being knows that he is suffering and wonders why" Suffering can lead to a rediscovery of how God created man to be. Man was not created to live in self-sufficient isolation, for "It is not good for the man to be alone" (Gen 2:18). Instead, suffering reminds man of his dependence on something greater than himself for life. This dependence is an invitation from God our Creator to a life of communion.

\subsection{Suffering and Original Unity}

While suffering tends to isolate a person, it can also make man aware of his openness to others through vulnerability. It can create a path to opening oneself from the self-enclosing walls of self-sufficient autonomy to communion with God and others. As John Paul II notes, "'suffering' seems to be particularly essential to the nature of man. [...] Suffering seems to belong to man's transcendence: it is one of those points in which man is in a certain sense 'destined' to go beyond himself, and he is called to do so in a mysterious way." ${ }^{38}$ In asking for help (whether to God or to others), the suffering person is led out of themselves and restores the possibility of growing in relations and communion.

In recognizing the suffering of another, man feels an interior call to help this person. Here we see the possibility of making a gift of oneself to another, in this case through compassion. "We are not allowed to 'pass by on the other side'

${ }^{56}$ John Paul II, Salvifici doloris, 6.

${ }^{57}$ John Paul II, Salvifici doloris, 9.

${ }^{58}$ John Paul II, Salvifici doloris, 2. 
indifferently; we must 'stop' beside him. Everyone who stops beside the suffering of another person, whatever form it may take, is a Good Samaritan. This stopping does not mean curiosity but availability. It is like the opening of a certain interior disposition of the heart, which also has an emotional expression of its own. The name 'Good Samaritan' fits every individual who is sensitive to the sufferings of others, who 'is moved' by the misfortune of another." ${ }^{59}$

In the suffering person an unspoken imperative moves the hearts of those around him. ${ }^{60}$ Suffering compels people to offer help, to become personally involved with the other. Through compassionate giving, man not only helps the other, but John Paul II recognizes that "He puts his whole heart into it ... he gives himself, his very 'I', opening this 'I' to the other person. Here we touch upon one of the key-points of all Christian anthropology. Man cannot fully find himself except through a sincere gift of himself' (Gaudium et Spes, 24)."61 In compassion, we see the fulfillment of Original Unity. The gift of the other calls man to communion through the gift of self, through living for and with the other. Furthermore, our neighbor's suffering reawakens in us the question of our own origin, reinforces our dignity, and calls us to seek the original goodness that preceded this suffering. ${ }^{62}$

For the suffering person, the experience of compassion is at the same time a reawakening and confirmation of his dignity. In the experience of someone taking care of him, of suffering with him, he recognizes that he is not alone, and begins to sense an answer to the question to God regarding the meaning of suffering. He begins to see that "suffering, which is present under so many different forms in our human world, is also present in order to unleash love in the human person, that unselfish gift of one's 'I' on behalf of other people, especially those who suffer. The world of human suffering unceasingly calls for,

59 John Paul II, Salvifici doloris, 28.

${ }^{60}$ Cf. E. Levinas, Totality and Infinity: An Essay on Exteriority. Norwell, MA 1991: Kluwer Academic Publishers, 197-201.

${ }^{61}$ John Paul II, Salvifici doloris, 28.

${ }^{62}$ Cf. J. Granados, Toward a Theology of the Suffering Body, "Communio" 33, no. 4, (Winter 2006), 556: “Through our neighbor's suffering we are reminded of our reference to God, which is what constitutes our dignity. This is because our suffering with our neighbor, flesh of our flesh, means the reawakening in us, through our own compassionate suffering, of the question of the origin, of the need to look for the good that precedes all evil." 
so to speak, another world: the world of human love; and in a certain sense man owes to suffering that unselfish love which stirs in his heart and actions." ${ }^{\text {"63 }}$

While the suffering person begins by asking God "Why?", through the experience of the love and care of a good Samaritan, the question is slowly transformed. Now man asks instead, "Why does God love me so much that he has sent this person to love me?" This rebuilds love in the heart of the sufferer, gives him strength and hope in his suffering, as well as the desire to find a way to love in return, to be more compassionate.

Suffering, then, becomes fruitful, in that the experience of compassion leads the suffering person to become more compassionate himself. While suffering may begin as an isolating experience, it can open man to being more aware of and compassionate to the suffering of others. Often people are consumed by their own daily concerns and can forget or be indifferent to the sufferings of others. But the suffering person can recognize solidarity with all who suffer, even if his suffering manifests itself in diverse ways. "The world of suffering possesses as it were its own solidarity. People who suffer become similar to one another through the analogy of their situation, the trial of their destiny, or through their need for understanding and care, and perhaps above all through the persistent question of the meaning of suffering. Thus, although the world of suffering exists 'in dispersion', at the same time it contains within itself a singular challenge to communion and solidarity." ${ }^{\text {" }}$

Rather than look at the suffering of others as a burden or threat, the person who has suffered can now look at them with love and compassion. In this way, he is able to recognize that the dignity of the person is not reduced because of suffering. He sees in the other a gift from God, not for his own interests, but in themselves. In the same way, he reaffirms his own dignity.

\subsection{Suffering and Original Nakedness}

In the suffering body, the contingent nature of life becomes more visible. Though man tries to find security in his plans or possessions, he realizes that suffering and death are unavoidable. This calls man to confront his need for God, as both

\footnotetext{
${ }^{63}$ John Paul II, Salvifici doloris, 29.

${ }^{64}$ John Paul II, Salvifici doloris, 8.
} 
origin and end.$^{65}$ In his vulnerability, man grows in awareness of his dependence on God and others. While man may be tempted to look down on the suffering, vulnerable and disabled because of their dependence on others, man's bodily experience of vulnerability and contingency shows that each person is dependent on others in greater or lesser degrees. There is no one who can say that he is completely independent, without need of God or others. This is particularly evident at the beginning and end of life, in infancy and old age, and in sickness. It is those who are suffering, vulnerable and disabled that speak through their bodies of the unconditional dignity of human life, of its nature as a gift. ${ }^{66}$ The fullness of life is lived in relation and communion. In these relations, not everyone will give and receive the same things, but there is no one who only receives. For even those that are the most dependent give the gift of drawing love out of those who care for them. ${ }^{67}$ In this way, they contribute to building a civilization of love.

Beyond contingency, the suffering body speaks of sinfulness. The person who suffers can become aware that in suffering, an experience of evil, there is a lack of goodness. While, at first, this may lead to the desire to eliminate the suffering, this experience may provide man with an opportunity to examine his life more closely. This can lead to a greater awareness of his own sinfulness: the times he has failed to accept his life and the lives of others as a gift. Thus suffering can have a purifying effect on him, which leads to recuperating a vision of the original goodness with which he was created, in contrast to his present awareness of his sinfulness. John Paul II notes that "the awareness of sinfulness is not only a necessary point of departure in 'historical' man, but also an indispensable condition of his aspiration to virtue, to 'purity of heart,' to perfection." ${ }^{68}$ The person who suffers becomes aware not only of his need for healing, but of a more complete healing - that of redemption.

${ }^{65}$ Cf. John Paul II, Man and Woman, 19:6, 204: "In looking to his origin, to the mystery of creation, man recognizes that "the fruit of the divine economy of truth and love, which revealed itself 'at the beginning,' is not Death, but Life, and not so much the destruction of the body "of man made 'in the image" of God,' but rather the 'call to glory' (Rom 8:30)."

${ }^{66}$ Cf. Gaudium et spes, 35: "A man is more precious for what he is than for what he has."

${ }^{67}$ Cf. S. Kampowski, Contingenza creaturale e gratitudine, Siena 2012: Cantagalli, 43-44.

${ }^{68}$ John Paul II, Man and Woman, 49:7, 325. 


\section{Christ's Suffering and the Recovery of the Original Experiences}

Through this evaluation of suffering and the original experiences, we are beginning to see why Jesus had to come Incarnate in order to redeem humanity. In order to free man from his sin and return to the original goodness of "the beginning," this could not be done merely by magic words of God. Though God could forgive humanity, it was humanity who was incapable of accepting this forgiveness. Since the logic of love that was stamped in man's body had been obscured, God needed to create "the possibility of rebuilding goodness in the subject," ${ }^{\prime \prime 9}$ so that the body would once again be open to and manifest love. In order to do this, Christ could not have taken on the boundary experience of shame, since he did not suffer from the interior imbalance of concupiscence. Suffering, as we have seen, is also a boundary experience that can reveal both man's inherent dignity and his call to transcendence. ${ }^{70}$ Since suffering is "essential to the nature of man," ${ }^{\text {11 }}$ Christ is able to redeem suffering and transform it into a path to redemption. ${ }^{72}$ Now, through Christ, suffering can fully reveal the love of the Father that is at the foundation of all of man's original experiences.

\subsection{Christ and Original Solitude}

Original Solitude shows that man's body is open to communion with God and others. This is brought to fulfillment in the Incarnation. In becoming man, Christ assumed the same flesh that we share. Recall that the body is immersed in time and is always relational. Being born of Mary, Jesus is connected through his flesh to the entire genealogy of God's people, to all of human history, leading back to Adam and Eve and to humanity's common origin in "the beginning". The novelty is in Jesus' virginal birth. While all of humanity comes from the Father, Christ, being born of the Virgin Mary, comes directly from the Father. In Jesus' body, as son of the Virgin and Son of God, we see a total reference to the Father: "He who sees me, sees the Father" (Jn 14:9) Thus, the body of Jesus renders visible

\footnotetext{
${ }^{69}$ John Paul II, Salvifici doloris, 12.

${ }^{70}$ Cf. J. Granados, "Toward a Theology of the Suffering Body," 558.

${ }^{71}$ John Paul II, Salvifici doloris, 2.

${ }^{72}$ Cf. John Paul II, Salvifici doloris, 19.
} 
in the world the original love of the Creator in a radical way. Jesus, as eternal Son, enters into time in order to initiate a new beginning, reconnecting humanity to the original love of the Father.

Christ's sonship is not only revealed in his birth, but also in his awareness of coming from the Father in every moment of his life. His entire existence is perfect receptivity to the will of the Father. St. Paul says that "Although he was a son, Christ learned obedience through what he suffered" (Heb 5:8). This learning of obedience does not refer to a lack of knowledge that Jesus had to learn through trial and error. Through his divine nature he always possessed the fullness of knowledge. Rather, it refers to his experiential knowledge through his human will, which he always experienced in light of his knowledge of himself as Son of God through his divine intellect. Therefore, he is able to learn obedience in his human nature by passing through the human trials of suffering and death with complete filial receptivity and trust. Through his obedience, goodness is rebuilt in the human heart, which had cast God out through sin. Unlike Adam, who tried to grasp the divinity of the Father himself, St. Paul tells us that Jesus, "though he was in the form of God, did not count equality with God a thing to be grasped, but emptied himself, taking the form of a servant, being born in the likeness of men. And being found in human form he humbled himself and became obedient unto death, even death on a cross" (Phil 2:6-9). Jesus shows that even in the face of suffering and death, man can accept God's will in freedom, with filial trust in God's love and goodness. ${ }^{73}$ Man is not abandoned by God in suffering, but called to even greater communion.

Since the Father is the original giver of all gifts, redemption begins with the Father's giving of his Son out of love for the humanity. As St. John tells us: "For God so loved the world that he gave his only Son, that whoever believes in him should not perish but have eternal life" (Jn 3:16). Analyzing the word "gave," John Paul II notes: "The very word 'gives' ('gave') indicates that this liberation must be achieved by the only-begotten Son through his suffering. And in this, love is manifested, the infinite love both of that only-begotten Son and of the

${ }^{73}$ Cf. K. Wojtyła, Sign of Contradiction. New York 1979: The Seabury Press, 150: "For Christ as well as for man, obedience is not only the renunciation of the supremacy of one's will, but above all, an opening to the perception of the love of God. Obedience and freedom coexist in truth." 
Father who for this reason 'gives' his Son. This is life of man, love for the 'world': it is salvific love." 74

The Father gives his Son to humanity in order to reveal his love for humanity. In the words of Vatican II, "In reality it is only in the mystery of the Word made flesh that the mystery of man truly becomes clear [...] Christ the new Adam, in the very revelation of the mystery of the Father and of his love, fully reveals man to himself and makes his supreme calling clear." ${ }^{35}$ Through his suffering, Christ reveals the original love of the Father as the only true comfort to humanity's suffering. And he calls us to salvation through participation in his sonship.

\subsection{Christ and Original Unity}

Not only is Christ given to the world by the Father, but he also sees humanity as a gift entrusted to him from the Father. Jesus, the true Good Samaritan, sees humanity suffering from the consequences of sin. Christ sees each person as "flesh of his flesh," as someone loved by the Father, whose dignity is rooted in the goodness of "the beginning," before evil has entered man's heart. ${ }^{76}$ As John Paul II explains: "In his suffering, sins are cancelled out precisely because he alone as the only-begotten Son could take this upon himself, accept them with that love for the Father which overcomes the evil of every sin; in a certain sense he annihilates this evil in the spiritual space of the relationship between God and humanity, and fills this space with good."77Thus the forgiveness offered

${ }^{74}$ John Paul II, Salvifici doloris, 14. Cf. 16: "Christ goes toward his own suffering, aware of its saving power; he goes forward in obedience to the Father, but primarily he is united to the Father in this love with which he has loved the world and man in the world."

${ }^{75}$ Gaudium et spes, 22, in Vatican Council II, Volume 1: The Conciliar and Postconciliar Documents, Ed. A. Flannery, O.P., new rev. ed., Northport, New York 1992: Costello Publishing. Cf. John Paul II, Salvifici doloris, 31: "If these words refer to everything that concerns the mystery of man, then they refer in a very special way to human suffering. Precisely at this point the 'revealing of man to himself and making his supreme calling clear' is particularly indispensable."

${ }^{76}$ Cf. J. Granados Garcia, La carne si fa amore: Il corpo, cardine della storia della salvezza. Siena 2010: Cantagalli, 208: "Cristo è in grado di affermare la dignità dell'uomo, poiché egli vede nell'uomo, suo fratello, qualcuno amato dal Padre fino alla fine. Tale dignità, in quanto affermata dallo stesso Figlio di Dio, è molto più originaria di qualsiasi male radicale presente nel cuore del peccatore. Perciò il perdono, quando è offerto da Cristo, è la possibilità reale di ritornare all'inizio, poiché Gesù stesso proviene proprio da questo inizio nel seno del Padre.”

77 John Paul II, Salvifici doloris, 17. 
by Christ through the Cross is capable of truly bringing us back to "the beginning," because he is the eternal Son through whom "all things were created," and who is "before all things," (Col 1:16, 17).

Christ accepts humanity as a gift from the Father, and he in turn gives himself for humanity. Thus in Christ's suffering body we see the fullest meaning of the body: "this is my body, given up for you" (Lk 22:19). Suffering is not merely an evil that he passively endures, but becomes the way through which he actively gives himself to humanity, uniting himself with us, and offering himself for our redemption. As Christ tells his disciples at the Last Supper, "Greater love has no man than this, that a man lay down his life for his friends" (Jn 15:13). Whereas suffering can be an experience of evil that one passively suffers, in Christ's compassionate gift of himself for humanity, we see that suffering can be transformed into an active manifestation of love.

But how does the suffering of one individual become a means of union and salvation for all? As we have seen, the suffering body opens man up to a world of solidarity between all who suffer, and can bring communion between them through the dynamism of compassion. On the Cross, Christ joins humanity in our cry to God in the face of suffering, as he cried out, "My God, My God, why have you forsaken me?" (Mt 27:46). John Paul II notes that "In that experience, in that cry, in that 'why' addressed to heaven, Jesus also established a new manner of solidarity with us who are so often moved to raise our eyes and words to heaven to express our complaint and even desperation." ${ }^{38}$ He shows that God is not deaf to our suffering. He gives his Son, so that through Christ's suffering and death he can unite himself with all who suffer. ${ }^{79}$ In this we see that "The redemptive value comes [...] from the fact that the innocent Jesus, out of pure love, entered into solidarity with the guilty and thus transformed their situation from within." Through Christ, man's body is "no longer under the sign of opposition to God. On the contrary, it is under the sign of docility to the love which comes from God (cf. Gal 1:4), and therefore becomes a source of blessing ( $\mathrm{Gal}$ 3:13-14)." ${ }^{80}$ Man's suffering no longer speaks only of separation from God, but of openness and docility to the revelation of God's love. The meaning of suffering

${ }^{78}$ John Paul II, Jesus, Son and Savior: A Catechesis on the Creed. Boston 1996: Pauline Books and Media, 471.

${ }^{79}$ Cf. Gaudium et spes, 22: "For by His incarnation the Son of God has united Himself in some fashion with every man."

${ }^{80}$ John Paul II, Jesus, Son and Savior, 445. 
has been completely transformed. Though suffering is not eliminated from man's historical existence, "The evil of suffering, in the mystery of Christ's redemption, is overcome and in every case transformed. It becomes a force of liberation from evil, for the victory of the good." ${ }^{11}$ Now suffering, as a boundary experience, becomes a path to conversion, to rebuilding goodness in man's heart. Thus "In the Cross of Christ not only is the Redemption accomplished through suffering, but also human suffering itself has been redeemed." ${ }^{\text {22 }}$ Now suffering has become the place where love is revealed to us.

\subsection{Christ and Original Nakedness}

In Christ's suffering body the love of the Father is fully revealed. We see that the Father is not some vengeful deity whose anger is only satisfied by the blood of his Son. Rather, He calls his Son to take our suffering upon himself, in order to destroy sin and death, which had separated man from unity with God. ${ }^{83}$ Thus "Human suffering has reached its culmination in the passion of Christ. And at the same time it has entered into a completely new dimension and a new order: it has been linked to love [...] to that love which creates good, drawing it out by means of suffering." ${ }^{\text {"I }}$ It is not that God had ceased loving humanity, and therefore demanded Christ's death in order to become compassionate again. For God has continuously offered his merciful love to humanity. Instead, it was man, who needed to be freed from the shackles of sin, so that he could accept God's merciful love. Salvation doesn't change God, but us. ${ }^{85}$

81 John Paul II, Jesus, Son and Savior, 454.

${ }^{82}$ John Paul II, Salvifici doloris, 19.

${ }^{83}$ Cf. John Paul II, Salvifici doloris, 18: “Together with this horrible weight, encompassing the "entire" evil of the turning away from God which is contained in sin, Christ, through the divine depth of his filial union with the Father, perceives in a humanly inexpressible way this suffering which is the separation, the rejection by the Father, the estrangement from God. But precisely through his suffering he accomplishes the Redemption, and can say as he breathes his last: 'It is finished' (John 19:30)."

${ }^{84}$ John Paul II, Salvifici doloris, 18.

${ }^{85}$ Cf. R. Cessario, The Godly Image: Christ and Salvation in Catholic Thought from Anselm to Aquinas, New York 2002: Fordham University Press, 165: "If Christ substitutes for sinful man in the experience of his passion, he does so only to enable men and women themselves to experience again the compassion of God. It is not that God then resumes being compassionate; rather, the human person is then free to accept God's love. All in all, [salvation] changes us, not God." 
We see also that Christ's risen body retains the wounds of his Passion. Thus we see that Christ's Passion does not end suffering and death as a human reality. However, "it nevertheless throws a new light upon this dimension and upon every suffering: the light of salvation." ${ }^{\text {"I }}$ In Christ's risen body, the wounds become a sign of Christ's total openness to God's love, and his total gift of himself for humanity. "Through the Resurrection, he manifests the victorious power of suffering, and he wishes to imbue with the conviction of this power the hearts of those whom he chose as Apostles and those whom he continually chooses and sends forth." ${ }^{87}$ In Christ's body given for us, we see an invitation to participate in Christ's redemptive suffering through our own suffering, thereby offering ourselves with Christ for our own redemption and the redemption of others.

\section{Participation in Christ's Redemptive Suffering}

In Salvifici doloris John Paul II shows that Christ transforms the passive experience of suffering through his active offering of himself, in order to incorporate men of all time into this redemption. Man is created with self-determination and free will, therefore he cannot be redeemed against his will. ${ }^{88}$ Man receives redemption as a gift, which calls for a response, for man's participation, through which he shares in the act of redemption throughout the whole of his life lived in union with Christ. Just as Christ actively took on suffering and transformed it into an expression of God's love, so man is called to discover, in his own suffering, the means of redemption. It is no longer something that just happens to man, in which man finds himself the victim. Suffering both symbolizes and

${ }^{86}$ John Paul II, Salvificidoloris, 18.

87 John Paul II, Salvifici doloris, 25.

${ }^{88}$ Cf. K. Wojtyła, Love and Responsibility, San Francisco 1981: Ignatius Press, 27: "Nobody can use a person as a means toward an end, no human being, nor yet God the Creator. On the part of God, indeed, it is totally out of the question, since, by giving man an intelligent and free nature, he has thereby ordained that each man alone will decide for himself the ends of his activity, and not be a blind tool of someone else's ends. Therefore if God intends to direct man toward certain goals, he allows him to begin to know those goals, so that he may make them his own and strive toward them independently. In this amongst other things resides the most profound logic of revelation: God allows man to learn His supernatural ends, but the decision to strive towards an end, the choice of course, is left to man's free will. God does not redeem man against his will." 
manifests Christ's redemption in the person's body. Through this, the filial, spousal and generative meaning of the body is both revealed and redeemed.

\subsection{Filial: Divine Adoption}

Through baptism, Christians enter into a new relationship with Christ, through which we are united to his suffering and death. ${ }^{89}$ As St. Paul taught, "Do you not know that all of us who have been baptized into Christ Jesus were baptized into his death? We were buried with him by baptism into death, so that as Christ was raised from the dead by the glory of the Father, we too might walk in newness of life" (Rom 6:3-4). In baptism we have become participants in his suffering and death, through "divine adoption" as sons and daughters in the order of grace. Not only do we merit the rewards of his redemptive act, as if we ourselves suffered and $\operatorname{died}^{90}$, but we are called to share in Christ's suffering and to unite our sufferings with his, thereby participating in our own redemption and that of the whole world. Thus we can say that, just as marriage is consummated in the spousal union of man and woman, so the vows of baptism are consummated in man's offering of himself in suffering.

John Paul II notes a twofold dimension of our participation in Christ's suffering. First, "this happens because Christ has opened his suffering to man, because he himself in his redemptive suffering has become, in a certain sense, a sharer in all human sufferings." ${ }^{\text {"91 }}$ In Christ's suffering we rediscover our own suffering. We come to recognize that when we suffer we are not alone, because we encounter Christ who took our suffering upon himself. Secondly, "Man, discovering through faith the redemptive suffering of Christ, also discovers in it his own sufferings; he rediscovers them, through faith, enriched with a new content and new meaning." ${ }^{\text {92 }}$ Christ has given new meaning to our experience

${ }^{89}$ Cf. J. Fitzmeyer, “The Letter to the Romans," New Jerome Biblical Commentary. Raymond Brown et. al. eds., Englewood Cliffs, NJ 1990: Prentice Hall, 847. “The rite of Christian initiation introduces a human being into union with Christ suffering and dying. Paul's phrase is bold; he wants to bring out that the Christian is not merely identified with the 'dying Christ' who has won victory over sin, but is introduced into the very act by which that victory has been won. Hence the Christian is 'dead to sin', associated with Christ precisely at the time when he formally became Savior."

90 Cf. Catechism of the Catholic Church, 1239.

91 John Paul II, Salvifici doloris, 20.

92 John Paul II, Salvifici doloris, 20. 
of suffering. It has become a revelation of God's love, that of redemption, and thus an invitation to realize this redemption through his suffering.

Suffering is not a problem to solve, but a mystery to enter into. In asking God the meaning of his suffering, man "cannot help noticing that the one to whom he puts the question is himself suffering and wishes to answer him from the Cross, from the heart of his own suffering." ${ }^{\text {"93 }}$ By contemplation of Christ's suffering, man slowly begins to recognize that the answer to the meaning of human suffering cannot be answered directly or abstractly, but only "as he himself gradually becomes a sharer in the sufferings of Christ." ${ }^{\prime 4}$ Only through participation does man gain true knowledge of the meaning of suffering. As John Paul II explains: "The answer which comes through this sharing, by way of the interior encounter with the Master, is in itself something more than the mere abstract answer to the question about the meaning of suffering. For it is above all a call. It is a vocation. Christ does not explain in theabstract the reasons for suffering, but before all else he says: 'Follow me!'. Come! Take part through your suffering in this work of saving the world, a salvation achieved through mysuffering! Through my Cross. Gradually, as the individual takes up his cross, spiritually uniting himself to the Cross of Christ, the salvific meaning of suffering is revealed before him." ${ }^{\prime 5}$

The meaning of suffering cannot be fully discovered on a human level, but only through transforming one's sufferings into a gift for and with Christ. Through this, man participates with Christ in the redemption of the world, and his sufferings take on meaning. In the process, gradually "the salvific meaning of suffering descends to man's level and becomes, in a sense, the individual's personal response. It is then that man finds in his suffering interior peace and even spiritual joy." ${ }^{\text {96 }}$ Far from being the passive victim of suffering, each person is called in a unique way to give meaning to their own suffering, gradually accepting suffering as a gift entrusted to them by the Father.

\footnotetext{
93 John Paul II, Salvifici doloris, 26.

94 John Paul II, Salvifici doloris, 26.

95 John Paul II, Salvifici doloris, 26.

96 John Paul II, Salvifici doloris, 26.
} 


\subsection{Spousal: United with his body, the Church}

How can man participate in Christ's suffering? In Christ's Passion he unites himself with all of humanity who suffers due to sin. This unity occurs through the "spousal nature" of the body, through which man is able to unite himself with another through the gift of self. John Paul II notes that in Christ's Passion, the "gift of self to the Father through obedience to the point of death (see Phil 2:8) is at the same time, according to Ephesians, an act of 'giving himself for the Church.' In this expression, redeeming love transforms itself, I would say, into spousal love"97. Through his redemptive act, Christ gives himself to the Church, and "united himself once and for all with her as the Bridegroom to the Bride"98. In this way, St. Paul says that "the two will form one flesh. This mystery is great; I say this with reference to Christ and the Church" (Eph. 5:32). As one flesh, the members of the Church are united with Christ, and therefore can share in both his sufferings and his redemption.

Union with Christ opens us up to participation. As John Paul II explains in Salvifici doloris: "The sufferings of Christ created the good of the world's redemption. This good in itself is inexhaustible and infinite. No man can add anything to it. But at the same time, in the mystery of the Church as his Body, Christ has in a sense opened his own redemptive suffering to all human suffering. In so far as man becomes a sharer in Christ's sufferings [...] to that extent he in his own way completes the suffering through which Christ accomplished the Redemption of the world." ${ }^{\prime 9}$

Through Christ's unity with the Church, his Body, human suffering has been opened up to his redemptive suffering. But if the goodness of Christ's redemption is infinite, in what sense can humanity "complete" the sufferings of Christ's redemption? This seems to imply that redemption is not complete. John Paul II continues: "Redemption, accomplished through satisfactory love, remains always open to all love expressed in human suffering. In this dimension the dimension of love - the Redemption which has already been completely accomplished is, in a certain sense, constantly being accomplished. [...] he did not bring it to a close." 100

\footnotetext{
97 John Paul II, Man and Woman, 90:6, 478.

98 John Paul II, Man and Woman, 90:6, 478.

99 John Paul II, Salvifici doloris, 24.

100 John Paul II, Salvifici doloris, 24.
} 
While our Redemption has been completely accomplished by Christ, it needs to be realized in time. Each person, through the encounter with Christ's redemptive love, becomes united to Christ. Because his love is infinite, it gives meaning to each of our actions, especially our sufferings. By opening ourselves to Christ's love in the midst of our suffering, we make up what is "lacking" in Christ's suffering: our participation in our redemption and his redeeming work.

\subsection{Generative: Fruitful Suffering}

The fruit of this union with Christ is its life-giving power. It is exactly in man's weakness, in his suffering, that the power of Christ's sacrifice can be made manifest. For "to suffer means to become particularly susceptible, particularly open to the working of the salvific powers of God, offered to humanity in Christ. [...] he wishes to make his power known precisely in this weakness and emptying of self." ${ }^{\prime 01}$ Those who suffer discover in their suffering a call, a "vocation," to allow their suffering to be transformed into the place where the power of Christ's redemptive sacrifice can bear fruit. Thus "the suffering person ... is serving, like Christ, the salvation of his brothers and sisters. Therefore he is carrying out an irreplaceable service. In the Body of Christ, which is ceaselessly born of the Cross of the Redeemer, it is precisely suffering permeated by the spirit of Christ's sacrifice that is the irreplaceable mediator and author of the good things which are indispensable for the world's salvation. It is suffering, more than anything else, which clears the way for the grace which transforms human souls. Suffering, more than anything else, makes present in the history of humanity the powers of the Redemption." ${ }^{102}$

Those who suffer may be tempted to view their suffering as useless, and may view themselves as a burden on others. This can lead to discouragement, depression and despair. However, through their suffering they are called to carry out an "irreplaceable service," by making the power of Redemption present in history. Unlike anything else, suffering prepares the way for grace. Therefore, suffering "has a special value in the eyes of the Church. It is something good, before which the Church bows down in reverence with all the depth of her faith in the Redemption." ${ }^{103}$ For in their sufferings, they preserve "a very special particle of the infinite treasure of the world's Redemption, and can share this treasure

101 John Paul II, Salvifici doloris, 23.

102 John Paul II, Salvifici doloris, 27.

${ }^{103}$ John Paul II, Salvifici doloris, 27. 
with others." ${ }^{104}$ In this sense the one who suffers may be in a better condition than one who doesn't experience suffering, and continues living their life under the illusion of self-sufficiency, while denying the very language of love and communion that is written into their body. Suffering, however, frees man from the blindness of concupiscence and calls him to rediscover the meaning of his body in the light of redemption. Thus, we see that "At one and the same time, Christ has taught man to do good by his suffering and to do good to those who suffer. In this double aspect he has completely revealed the meaning of suffering." ${ }^{105}$ In both ways, man's suffering is transformed into the path toward redemption, as he unites himself with Christ in offering himself for the redemption of others.

\section{Conclusion}

I have examined the redemptive role of suffering in light of John Paul II's Theology of the Body alongside his Apostolic Letter Salvifici doloris. I began by highlighting John Paul II's method, which appeals to both revelation and experience (2). I then examined the Original Experiences of man before sin, in order to understand the goodness of creation and the body (3). Both are gifts that God gave to man in order to bring him into relationship with Himself. The body was also created in order for man to recognize the same goodness in others, and thus to come to know God through interpersonal relationships and the experience of love. This comes through the acceptance of the other as a gift, and in giving oneself to others, thereby giving oneself also to God, the original giver and source of all goodness.

With Original Sin came suffering, death and the blinding to the reading of the language of the body due to concupiscence (4). Instead of seeing others as a gift, man now is often tempted to reduce others to their utilitarian value. Those who are suffering are in particular danger of being viewed as a burden: as a problem to be dealt with, or an obstacle to be eliminated. Man is also tempted to base the value of his life on the amount of pleasure that he experiences, on his quality of life. Since suffering can lessen a person's quality of life, it is often accompanied by a loss of one's intrinsic value.

\footnotetext{
104 John Paul II, Salvifici doloris, 27.

105 John Paul II, Salvifici doloris, 30.
} 
Suffering, like shame, can also have positive value as a boundary experience, which leads man to question his life and rediscover his Original Experiences (5). Through questioning the meaning of one's own suffering or the suffering of others, man puts himself in dialogue with God. This openness or vulnerability can lead also to opening himself up to receiving help from others, which leads to the experience of compassion and love. The experience of the suffering of another can open up compassion within the unaffected person as well. Man's suffering becomes an opening to communion with others, to solidarity, and the experience of love and compassion. Ultimately it can have a purifying effect on the sufferer, helping recuperate a vision of the original goodness for which he was created, and therefore reveals the need for healing and redemption.

In order to redeem our fallen humanity, Christ took on the boundary experience of suffering (6). As son of the Virgin and Son of God, his body is a total reference to the Father, and thus renders visible the original love of the Creator in a radical way. In his obedience to the Father's will, he opens the human heart once more to the Father's love, which had been cast out of man's heart through Original Sin. Since he is the eternal Son "before all things," (Col 1:17) and through whom "all things were created," ( $\mathrm{Col}$ 1:16) he is capable of uniting with humanity and bringing us back to the original goodness of "the beginning". Christ does not eliminate suffering but instead redeems it, transforming it into a revelation of God's love. Suffering becomes a path to conversion, to rebuilding goodness in man's heart, and to liberation from evil. Through his suffering, humanity is freed from the shackles of sin and is capable through the gradual redemption of the body, of loving purely.

Though Christ has redeemed us, we need to participate in this redemption in order to be healed from the effects of concupiscence and $\sin (7)$. Rather than view suffering as a problem to solve, it can become a mystery to enter into. Suffering both symbolizes and manifests Christ's redemption in the body. Christ does not give humanity an abstract reason for suffering, but invites us to follow him, participating through our suffering in the salvation that he achieved for us through his own suffering. Far from being a passive victim, each person is called to make a personal and active gift of his life through suffering. While our redemption has been completely accomplished by Christ, it lacks our own participation in time. Through this participation, we are united with Christ's redeeming love in his Body, the Church. Far from being useless, suffering thereby becomes transformed into a life-giving force that can be offered for one's own redemption and the redemption of others. 
By taking into account man's embodied nature and the revelatory nature of the body, John Paul II has demonstrated the value that suffering plays in man's redemption. His Theology of the Body runs contrary to the modernist position, that views the body as mere matter to be manipulated, modified or disposed of according to each individual's will. Man believes that if he reasons hard enough, he can end suffering, poverty, hunger, disease, war and even sin, through scientific, political and economic means. Material advancement, rather than redemption, has become the goal of human existence. ${ }^{106}$

Since suffering appears to threaten the accomplishment of this material advancement, modernity has attempted to eliminate it at all costs. This has led to numerous ethical issues. Contraception is used when someone desires to have sex, but does not want to suffer the consequences of a possible pregnancy and the responsibility of raising a child. Abortion is also used to eliminate an unwanted pregnancy, or to prevent the potential suffering of a child who would be born with a short life expectancy or possible physical or mental defects. Likewise end of life issues such as euthanasia and physician-assisted suicide eliminates a person whose suffering causes a lack of quality of life or a burden on others. In marriages also, spouses often choose divorce rather than suffer through the effort required to confront issues, forgive each other and make personal changes that would instead strengthen their marriages. In each of these cases, the person is reduced to an object whose worth and value is determined based on material goals, rather than in the greater vision of God's salvific plan for humanity. Suffering, or the potential to suffer, is avoided at all costs, rather than be accepted, embraced and offered for one's own salvation and the salvation of others.

Viewing the suffering body in light of John Paul II's Theology of the Body helps us to move away from this modernist, materialistic understanding of reality and return to a sacramental worldview that views all of creation as pregnant with mystery. Far from being merely matter, creation is a sign pointing to the Creator, who is intimately present within it and invites humanity to participation in His inner life through grace. This participation occurs not from fleeing from the material or the bodily dimensions of the world, but by embracing their deeper meaning revealed by Christ, the Church and the sacraments.

${ }^{106}$ For an analysis of the Modernist position Cf. M. Waldstein, "Introduction," in: John Paul II, Man and Woman He Created Them: A Theology of the Body, Trans. M. Waldstein, Boston 2006: Pauline Books and Media, 34-63, 94-105. 


\section{Bibliography}

Catechism of the Catholic Church, 2nd ed., Vatican translation, Rome 1997: Libreria Editrice Vaticana.

Cessario R., The Godly Image: Christ and Salvation in Catholic Thought from Anselm to Aquinas, New York 2002: Fordham University Press.

Fitzmeyer J., The Letter to the Romans, New Jerome Biblical Commentary, Raymond Brown et. al. eds., Englewood Cliffs, NJ 1990: Prentice Hall.

Granados J., The Suffering Body, Hope, and the Disclosure of the Future, "Communio" 36 (Winter 2009).

Granados, J., Toward a Theology of the Suffering Body, "Communio" 33, no. 4, (Winter 2006).

Granados Garcia J., La carne si fa amore: Il corpo, cardine della storia della salvezza, Siena 2010: Cantagalli.

Hauerwas S., Truthfulness and Tragedy: Further Investigations into Christian Ethics, Notre Dame IN 1977: University of Notre Dame Press.

John Paul II, Jesus, Son and Savior: A Catechesis on the Creed, Boston 1996: Pauline Books and Media.

John Paul II, Man and Woman He Created Them: A Theology of the Body, Trans. M. Waldstein, Boston 2006: Pauline Books and Media.

John Paul II, Apostolic Letter Salvifici doloris: On the Christian Meaning of Human

Suffering, Vatican Translation. Boston: Pauline Books and Media, (1.03.1984), AAS 76 (1984), 201-50.

Kampowski S., Contingenza creaturale e gratitudine, Siena 2012: Cantagalli.

Levinas E., Totality and Infinity: An Essay on Exteriority, Norwell, MA 1991: Kluwer Academic Publishers.

Vatican Council II, Gaudium et spes, in Vatican Council II, Volume 1: The Conciliar and Postconciliar Documents, Ed. Austin Flannery, O.P., new rev. ed., Northport, New York 1992: Costello Publishing.

Wojtyła K., Love and Responsibility, San Francisco 1981: Ignatius Press.

Wojtyła K., Sign of Contradiction, New York 1979: The Seabury Press. 